DOI https://doi.org/10.30525/978-9934-26-079-7-10

\title{
ХАРАКТЕРНІ ОСОБЛИВОСТІ БОРОТЬБИ З РАСИЗМОМ ТА АНТИСЕМІТИЗМОМ У БРИТАНСЬКІЙ СИСТЕМІ ОСВІТИ: 2020-2021 РР.
}

\author{
Козерод О. В. \\ доктор історичних наук, \\ стариий науковий співробітник \\ Інституту політичних і етнонаціональних досліджень \\ Національної академії наук Украӥни \\ м. Київ, Україна
}

Проблема боротьби 3 проявами расизму та антисемітизму в університетах та школах Великобританії продовжує залишатися актуальною. Склад студентів й учнів у навчальних закладах Сполученого Королівства традиційно є інтернаціональним і регулярно оновлюється, що вимагає постійної уваги з боку керівництва профільних міністерств та відомств, політиків, громадських діячів. Різні аспекти рівності прав представників різних національностей у Великобританії досліджувалися у збірках робіт під редакцією Бріджіт Бірн, Клейр Александр i Уільям Шенклі [1]. Питання расизму i антисемітизму у вищій освіті Великобританії були розглянуті у збірках праць під редакцією Джейсона Арді, Хейді Сафіi Мірзи [2], а такжо Шірлі Енн Тейт та Пола Баггулі [3].

Слід зазначити, що велику активність в сфері моніторингу расизму та антисемітизму демонструють організації самих національних меншин, які проводять велику роботу в цьому напрямку, допомагаючи владі вести боротьбу з даними явищами. Так, масштабне дослідження, присвячене антисемітизму в університетах Великобританії, було проведено наприкінці 2020 року за сприянням Общинного охоронного фонду (Community Security Trust), що відповідає за безпеку єврейських общин на всій території Великобританії. Проведене соціологами дослідження виявило, що антисемітизм досі широко поширений в британських вишах. У звіті CST, зокрема, зазначається, що за останні два академічних роки відбулося 123 антисемітських злочинів, скоєних студентами, академічним персоналом, представниками профспілки або членами студентських товариств. При цьому 39 інцидентів сталося на території кампусів і 51 - в мережі інтернет. CST зафіксував 15 інцидентів, до яких були причетні співробітники університетів, зокрема 4 відбулися в Університеті Ворика, 2 - в Університеті Лідса i 2 - в Університеті Ноттінгема. За словами лорда Джона Манна, дослідження CST свідчить про «культурну проблему», що має місце в університетських кампусах [4]. За даними CST, реакція адміністрації 
університетів була непослідовною й іноді навіть збільшувала шкоду, яку було завдано єврейським студентам. Так, в одному з випадків єврейський студент Університету Ворика піддався дисциплінарному стягненню з боку академічного персоналу після того, як повідомив адміністрації про те, що викладач зробив антисемітський коментар на лекції. «Найбільш серйозні випадки мають місце, коли університети відмовляють своїм студентам в адекватному захисті від проповідників ненависті серед викладачів або від політично упереджених вчених, що просувають теорії змови, зокрема про британських євреїв, антисемітизм та Лейбористську партію», - підкреслив генеральний директор CST Марк Гарднер [4]. Важливу роль у суспільній дискусії 2020-2021 років у Великобританії грало питання стосовно руху Black Lives Matter. Велика кількість академічних співробітників низки університетів країни зазнала гонінь та обструкції за висловлення своєї думки 3 цього приводу. Однією 3 найбільш показових стала історія 3 викладачкою Кембриджського університету, яка висловила сумнів в необхідності кампаній, подібних BLM. Доктор Пріямвада Гопал написала в Твітері: «White Lives Don't Matter», після чого отримала безліч образливих повідомлень та погроз розправи. У відповідь на це адміністрація університету заявила, що лектори та науковці мають право виражати свою власну думку [5]. 51-річна доктор Пріямвада Гопал, яка викладає на факультеті англійської мови в коледжі Черчилля, написала з цього приводу в Twitter: «Я скажу це знову. Білі життя теж не мають значення». Цей пост викликав шквал обурення, в Twitter були направлені сотні скарг, після чого пост було видалено. Після цього Гопал почала отримувати все більше звинувачень у расизмі й більше погроз вбивства. Один чоловік, зокрема, надіслав зображення петлі із підписом «Ми йдемо за тобою, чорт забирай...» Крім того, на сайті петицій change.org було запущено петицію під назвою «Професор расизму в Кембриджі», яка вимагає, аби доктор Гопал була звільнена 3 університету через свій коментар [5].

Проте керівництво університету вирішило не карати викладачку й навіть підвищило доктора Гопал до рівня професорки. У заяві, опублікованій університетом, зазначалося: «Університет захищає право своїх вчених висловлювати власні законні думки, які інші можуть вважати суперечливими. Висловлюємо жаль щодо появи образ та особистих обвинувачень. Ці атаки абсолютно неприпустимі й повинні припинитися» [5].

Тенденція протидії расизму під впливом руху Black Lives Matter відбилася й на роботі середніх шкіл. Так, керівники кращих приватних шкіл Великобританії заявили про бажання «деколонізувати» свої навчальні плани вивчення історії після появи протестів Black Lives Matter. В Единбурзі представники школи Fettes College, яку закінчив колишній прем'єр-міністр Великобританії Тоні Блер, заявили, що використовують цей момент як «каталізатор реальних змін в навчаль- 
них. програмах». Як зазначає сьогодні Daily Mail, провідні незалежні школи, такі як Winchester College, Fettes, Ampleforth та St Paul's Girls, вже «формулюють нові підходи» до викладання британського колоніального минулого. «Ми ініціювали перегляд навчальних програм i маємо намір завершити цей перегляд наступного семестру» [6], сказав представник Winchester College. Міністр освіти Великобританії Гевін Вільямсон також відреагував на ініціативу шкіл, заявивши, що діти повинні дізнатися про «хороше та погане» минуле країни. Він додав: «Абсолютно життєво важливо, неймовірно важливо, аби діти, дізнаючись про історію нашої країни, вивчали всі її аспекти» [6].

Слід зазначити, що рух BLM значною мірою вплинув на політику урядів західних країн, зокрема Великобританії, пов'язану з боротьбою iз расизмом та ксенофобією. При цьому внутрішня політика британського уряду змінилася меншою мірою, ніж в інших країнах, перш за все тому, що в країні вже діяли досить жорсткі норми боротьби 3 даними явищами, які роз'їдать єдність суспільства та загрожують розвитку демократії. Проте система освіти залишається одним 3 найскладніших напрямків для політики уряду у зв'язку з наявністю великої кількості іноземних студентів та легкістю проведення пропагандистської роботи в умовах автономії вишів та шкіл, а також високим рівнем академічних свобод, що існують у Великобританії.

\section{Література:}

1. Ethnicity, Race and Inequality in the UK: State of the Nation by Bridget Byrne, Claire Alexander, William Shankley. Bristol. Policy Press. 2020. 289 pp.

2. Dismantling Race in Higher Education: Racism, Whiteness and Decolonising the Academy by Jason Arday, Heidi Safia Mirza. London. Palgrave Macmillan. 2018. 396 pp.

3. 3.Building the Anti-Racist University by Shirley Anne Tate, Paul Bagguley. London. Routledge. 2020. 156 pp.

4. Campus Antisemitism in Britain: 2018-2020. Community Security Trust: веб-сайт. URL: https://cst.org.uk/news/blog/2020/12/17/campusantisemitism-in-britain-2018-2020 (дата звернення: 17.12. 2020).

5. Cambridge University backs academic who tweeted 'White Lives Don't Matter' - and Promotes her to professor - after she received barrage of abuse and death threats. Daily mail: веб-сайт. URL: $\quad$ https://www.dailymail.co.uk/news/article-8460059/CambridgeUniversity-backs-academic-tweeted-White-Lives-Dont-Matter.html (дата звернення: 25.06. 2020).

6. Top private schools plan to 'decolonise' syllabuses and reconsider cultures. The Telegraph: веб-сайт. URL: https://www.telegraph.co.uk/ news/2020/06/20/private-schools-look-decolonise-syllabuses-black-livesmatter/ (дата звернення: 20.06. 2020). 